\title{
On-farm Performance Evaluation of Rhodes Grass (Chloris gayana) Cultivars Under Rain-fed Condition at Babile District of East Hararghe, Oromia, Ethiopia
}

\author{
Melese Furgasa $^{1^{*}} \quad$ Tolera Fikadu $^{1} \quad$ Wubishet Tesfaye $^{2} \quad$ Worku Bekuma $^{2}$ \\ 1. Range Ecology and Biodiversity, Fedis Agricultural Research Center, Oromia Agricultural Research Institute, \\ P.O. box 904, Harar, Ethiopia \\ 2. Animala Nutrition, Fedis Agricultural Research Center, Oromia Agricultural Research Institute, \\ P.O. box 904, Harar, Ethiopia
}

This research/experiment is financed by Oromia Agricultural Research Institute (OARI).

\section{Abstract}

The experiment was executed by Fedis Agricultural Research Center (FARC) for two consecutive years (2017/18 and 2018/19). It was conducted on-farm at Babile district of Bishan Babile and Ifa kebeles with 5 Rhodes grass (Chloris gayana) cultivars namely; ILRI-7384, CV-massaba-13329, ILRI-6633, DZ-253 and local check. Experimental plots were laid out in a randomized completely block design (RCBD) with three replications with the objective of selecting/recommending high biomass yielding and adaptable Rhodes grass (Chloris gayana) cultivars to the study area and other districts having the same agro-ecologies. The over year and over location statistically analysis result showed there is a significant difference $(\mathrm{P}<0.05)$ observed among the mean values of days to emergence, days to $50 \%$ flowering, dry Biomass yield and seed yield parameters. Maximum number of days required for first emergence was 10.42, 10.25 and 10.33 for cultivars of Rhodes DZ253, ILRI-6633 and ILRI-7384; whereas the minimum days to emergency recorded was 8.83 and 9.08 for, local check and CV-massaba-13329 respectively. The mean numbers of days to 50\% flowering for cultivar DZ-253 was 110.67 days followed by ILRI-6633 (109.83 days) and local check (109.33 days). The minimum days to 50\% flowering obtained were 108.83 days and 108.92 days for ILRI-7384 and CV-massaba-13329 respectively. The maximum dry biomass yield of Rhodes grass was recorded by DZ-253 ( 9.42 ton ha $^{-1}$ ) followed by local check $\left(8.5\right.$ ton $\left.\mathrm{ha}^{-1}\right)$. Whereas, the minimum aboveground dry biomass yields obtained were $7.53,7.79$ and 7.95 (ton ha${ }^{1}$ ) for CV-massaba-13329, ILRI-7384 and ILRI-6633 respectively. In general DZ-253 and local check give higher aboveground dry matter yield than the rest cultivars. It is concluded that DZ-253 and local check are more desirable and recommended to demonstrate in the study area and districts having similar agro ecologies.

Keywords: Chloris Gayana, Dry Biomass Yield, Fodder Grass.

DOI: $10.7176 / \mathrm{JBAH} / 11-3-03$

Publication date: February $28^{\text {th }} 2021$

\section{Introduction}

In developing countries livestock sector plays an important role in contributing for food and nutritional security and serves as an important source of livelihood for nearly one billion poor people (Frans and Siboniso, 2010). Keeping livestock is an important risk reduction strategy for vulnerable communities, an important provider of nutrients and traction for growing crops in small holder systems. Livestock products like milk, meat and other products contribute 17 percent to kilocalorie consumption and 33 percent to protein consumption globally (Melkamu, 2014).Cattle largely depends on rangeland grazing or crop residues that are of poor in quantity and quality (i.e. nutritive value). Seasonal fluctuation in the availability and quality of feed has been serious challenges in livestock production (Mengistu, 2005). The feed shortage mostly happens in dry season of the year (Ibrahim and Olaloku, 2000). To overcome this bottleneck problem of livestock sector introducing improved forages to livestock stakeholders should have to be an obligatory and persistent activity that is expected from responsible service providers.

Rhodes grass (Chloris gayana) is a perennial or annual tropical leafy grass 1-2 $\mathrm{m}$ in height, highly variable in habit. The culms are tufted or creeping, erect or decumbent, sometimes rooting from the nodes. The roots are very deep, down to $4.5 \mathrm{~m}$. The inflorescences are light greenish brown (rarely yellow) in color and turn darker brown as they mature (Cook et al., 2005).

Rhodes grass (Chloris gayana) thrives in places where annual temperatures range $25-30^{\circ} \mathrm{C}$ (day/night temperature). Optimal annual rainfall ranges between $600-750 \mathrm{~mm}$ with a summer-rainfall period (Cook et al., 2005, Moore, 2006 and Ecocrop, 2014). Rhodes grass grows better in areas where with an altitude ranges from 1400 - 2400 masl (Cook et al., 2005 and Ecocrop, 2014). Rhodes grass can survive in areas where annual rainfall ranges between $310 \mathrm{~mm}$ and $4030 \mathrm{~mm}$ and where temperature extremes are $5{ }^{\circ} \mathrm{c}$ and $50{ }^{\circ} \mathrm{c}(\mathrm{Cook}$ et al, 2005).

Due to its deep roots, Rhodes grass can withstand long dry periods (over 6 months) and up to 15 days of flooding (Cook et al., 2005 and FAO, 2014). Seasonal water logging over $30 \mathrm{~cm}$ kills the plant (FAO, 2014). 
Rhodes grass grows on a wide range of soils from poor sandy soils to heavy clayey alkaline and saline soils. This salt tolerance is particularly valuable in irrigated pastures where it can be cultivated without problem. Rhodes grass grows better on fertile, well-structured soils and it prefers soil $\mathrm{pH}$ between 5.5 and 7.5; even if, establishment on acidic soils is challenging. Rhodes grass grows well on a drained moderate to high fertility soils and survives on infertile soils although it is unproductive and may eventually die out particularly if grazed regularly. Rhodes grass is a full sunlight species, which does not grow well under shady environments (Cook et al., 2005, FAO, 2014 and Ecocrop, 2014).

It stands up to the height of $90 \mathrm{~cm}$ (FAO, 2009). The heights of Rhodes plant when measured reached $0.5-$ $1.2 \mathrm{~m}(50-120 \mathrm{~cm})$ and tillers measured $0.9-2.0 \mathrm{~m}(90$ to $200 \mathrm{~cm})$ tall. Height of Rhodes plants grown sole on savannah regions of Ethiopia at 8 weeks after sowing varied from 100.7 to $121.0 \mathrm{~cm}$ tall (Yesihak, 2008).

Growth performance of Rhodes grass varies with type of cultivar, age of plant and other environmental factors (Duke, 1997, FAO, 2009 and Akinola et al., 1990). Rhodes grass productivity generally ranges from 7 25 tons of $\mathrm{DM} \mathrm{ha}^{-1}$ per year, depending on variety, soil fertility, environmental conditions and cutting frequency. Based on a study conducted on farmers' fields in the central highlands of Ethiopia, on average the herbage yield of Rhodes grass was from 8.74 to 9.1 tons $\mathrm{DM} / \mathrm{ha}^{-1}$ per year on rain-fed conditions (Cook et al., 2005, CASCAPE, 2015 and HARC, 2004).

Therefore, this study was done with the objective to observe the adaptability and evaluate the biomass yield performance of Rhodes grass in the selected kebele of Babile districts of Oromia region, Ethiopia.

\section{Materials and Methods}

\subsection{Description of the study area}

The field trials were conducted for two consecutive years (2017/18 and 2018/19) at Bishan Babile and Ifa Kebeles of Babile district of East Hararghe. Babile district is found in the Oromia Regional State of Ethiopia. Babile district is located at $7^{\circ} 00^{\prime} 90^{\prime \prime}$ North Latitude and $43^{\circ} 0^{\prime} 00^{\prime \prime}$ East Longitude (MoA, 2014). Babile district shares boundary with Somali regional state and Fedis district of East Hararghe Zone of Oromia regional State. The total size of Babile district is estimated about $1,325 \mathrm{~km}^{2}$ which was divided into 17 kebeles and 42 subkebeles. The annual average temperature was 26.5 Celsius with uneven distribution rainfall (MoA, 2014). The people are dominantly agro-pastoral with $70 \%$ of the total population living on this mode of life. The remaining population, $15 \%$ are agricultural, $10 \%$ are pastoral, and $5 \%$ petty traders. Maize and sorghum are staple crops, and the livestock production includes: cattle, goats, sheep, and camels (MoA, 2014).

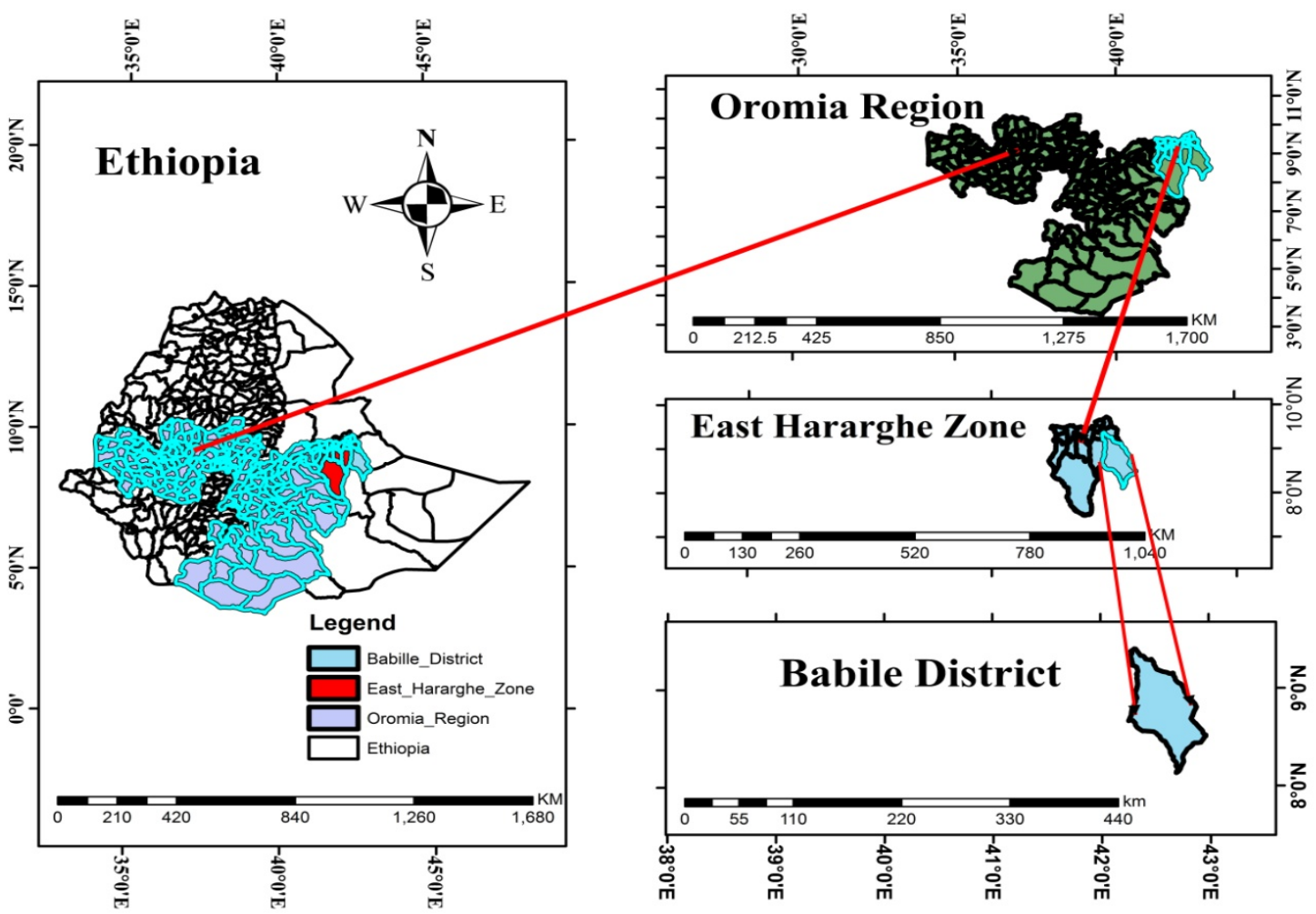

Figure: 1 Map Layout of Study Area 


\subsection{Field Preparation and Sowing}

The experimental land preparation was done by oxen driven local plough followed by manual ploughing implement (Akafa). The seeds were sown immediately after the beginning of the main rainy season. Sowing was done manually by drilling the seeds in the furrows at a depth of $1-2$ centimeters. Then the seed was covered with thin soil by over passing light sticks and fingers over the furrows.

\subsection{Experimental Design and Treatments}

Two farmers from Efa district and four farmers from Bishan Babile district were selected to conduct the experiment for two consecutive years. Rhodes grass cultivars were arranged in a randomized complete block design with three replications. The experiment was conducted using three replications with 5 Rhodes grass (Chloris gayana) treatments (i.e. ILRI-7384, CV-massaba-13329, ILRI-6633, DZ-253 and 1 local check). A single plot size was set with $2 \mathrm{~m} \times 2 \mathrm{~m}$ both at Bishan Babile and Ifa districts. A gap of $1 \mathrm{~m}$ between plot and replication was set with $0.25 \mathrm{~m}$ of spacing between rows where each experimental plot accommodates seven hedgerows. The seed rate was kept at $10-12 \mathrm{~kg} \mathrm{ha}^{-1}$ by considering the germination percentage of the experimental seeds. Three replications of each treatment were sown to minimize variation in soil physicochemical properties and other factors.

\subsection{Data Collection}

Primarily days of emergence, days to $50 \%$ flowering, a day to full maturity and plant height was recorded. Height of ten plants from each plot was taken randomly and their mean value was calculated accordingly. Consequently, fresh biomass yield was collected and calculated by selecting 3 middle lines and cutting at a stubble height of $5 \mathrm{~cm}$ and weighing to find out the weight of fresh biomass matter (Tessema and Yvan, 2007). Fresh biomass of the middle three lines were cut at a stubble height of $5 \mathrm{~cm}$ and weighed to find out the weight of fresh biomass matter (Tessema and Yvan, 2007). Fresh samples of 500gm were collected and submitted for dry matter weight analysis. Finally, the samples were oven dried at $105^{\circ} \mathrm{c}$ for 24 hours and weighed to determine the dry matter yield of herbages (Whelly and Hardy, 2000).

\subsection{Data analysis}

Data on statistical parameters of Rhodes grass accession samples were subjected to ANOVA based on the model designed for a randomised complete block design (RCBD) according to Gomez and Gomez (1984) and using the computer software package of SAS version 9.1. Mean separations were tested using the least significance difference (LSD) and significant level was considered at $(P<0.05)$.

The statistical model used for the RCBD design was:-

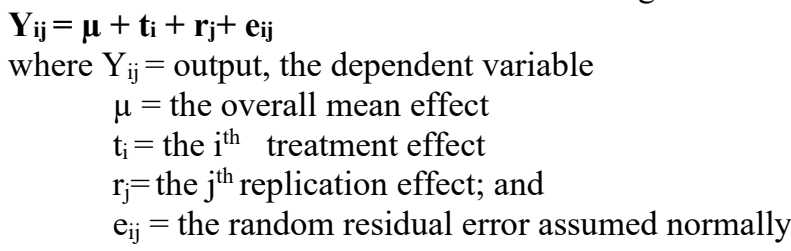

\section{Result and Discussion}

\subsection{Days to Emergence and Days of 50\% Flowering}

The over year statistical data analysis result indicates that there is a significant difference $(P<0.05)$ observed among Rhodes grass (Chloris gayana) cultivars on days of emergence (DE) and days of $50 \%$ flowering $(\mathrm{DF} \% \mathrm{~F})$. The mean number of days required for emergence was $10.25,9.08,10.33,10.42$ and 8.83 for ILRI-7384, CVmassaba-13329, ILRI-6633 and DZ-253 and local check respectively (Table 1). In this study Rhodes grass (Chloris gayana) cultivars required a range of $8.83-10.42$ days for first emergence which is almost similar with the study conducted at Deghabour district of Ethiopian Somalia region (Mohamed and Gebeyew, 2018) which was recorded 10.66 days. But, other study discovered that Rhodes grass germinates within 7 days after planting (Cook et al., 2005). The alteration on days to emergence might be attributed to soil moisture content, soil fertility and other environmental factors. 
Table 1. The mean value of yield and yield component of over year and over location of Rhodes grass accessions at Babile district.

\begin{tabular}{ccccccc}
\hline Treatments & DE & $\begin{array}{c}\text { DF } \\
(50 \%)\end{array}$ & DFM & $\begin{array}{c}\text { PH } \\
(\mathrm{cm})\end{array}$ & $\begin{array}{c}\text { DBMY } \\
(\mathrm{t} / \mathrm{ha})\end{array}$ & $\begin{array}{c}\text { Seed yield } \\
(\mathrm{Kg} / \mathrm{ha})\end{array}$ \\
\hline ILRI-7384 & $10.25^{\mathrm{a}}$ & $108.833^{\mathrm{b}}$ & 154.5 & 145.92 & $7.79^{\mathrm{b}}$ & $265.3^{\mathrm{c}}$ \\
CV-massaba-13329 & $9.08^{\mathrm{b}}$ & $108.92^{\mathrm{b}}$ & 155.5 & 144.83 & $7.53^{\mathrm{b}}$ & $252.0^{\mathrm{d}}$ \\
ILRI-6633 & $10.33^{\mathrm{a}}$ & $109.83^{\mathrm{ab}}$ & 155.33 & 136.08 & $7.95^{\mathrm{b}}$ & $275.7^{\mathrm{bc}}$ \\
DZ -253 & $10.42^{\mathrm{a}}$ & $110.67^{\mathrm{a}}$ & 151.83 & 147 & $9.42^{\mathrm{a}}$ & $291.3^{\mathrm{a}}$ \\
Local Check & $8.83^{\mathrm{b}}$ & $109.33^{\mathrm{ab}}$ & 151.73 & 145.92 & $8.50^{\mathrm{ab}}$ & $280.6^{\mathrm{ab}}$ \\
\hline Mean & $9.78^{\mathrm{b}}$ & 109.4 & 154.8 & 144.13 & 8.45 & 273 \\
CV & $2.46^{\mathrm{a}}$ & 0.97 & 1.5 & 5.02 & 12.03 & 2.08 \\
\hline
\end{tabular}

Where Mean within a column with different superscripts differ significantly $(\mathrm{P}<0.05), \mathrm{DE}=$ days to emergence, $\mathrm{DF} \% \mathrm{~F}=$ days to $50 \%$ flowering, $\mathrm{DFM}=$ days to full maturity, $\mathrm{PH}=$ plant height in centimeters, DMY $(\mathrm{t} / \mathrm{ha})=$ Dry Matter Yield $($ Ton per Hectare), CV = Coefficient of Variation, LSD = Least Significance Difference, NS= Not Significant.

The mean numbers of days to $50 \%$ flowering were $108.833,108.92,109.83,110.67$ and 109.33 for ILRI7384, CV-massaba-13329, ILRI-6633, DZ-253 and local check respectively. The difference in days to emergence and days to $50 \%$ flowering among treatments could be attributed to genetic variation among genotypes and their interaction with the environment.

\subsection{Days to Full Maturity and Plant Height}

Primarily, ANOVA table result for days to full maturity (DFM) and plant height ( $\mathrm{PH}$ ) reveals that there is no significant difference $(P>0.05)$ observed among the mean numbers of days to full maturity for all Rhodes grass (Chloris gayana) cultivars; though, the mean numbers of days to full maturity and plant height were numerically different. The mean numbers of days to full maturity were 154.5, 155.5, 155.3, 151.83 and 151.73 for ILRI-7384, CV-massaba-13329, ILRI-6633, DZ-253 and local check respectively (Table 1). But, numerically, this study revealed that CV-massaba-13329 and ILRI-6633 required more days to full maturity than other genotypes.

The mean plant height $(\mathrm{PH})$ values of Rhodes grass (Chloris gayana) cultivars was 145.92, 144.83, 136.08, 147.0 and 145.92 centimeters for ILRI-7384, CV-massaba-13329, ILRI-6633, DZ-253 and local check respectively (Table 1). Numerically, this study revealed that DZ-253 recorded higher plant height values than other cultivars. The average plant height values of Rhodes grass cultivars recorded in this study was almost similar with the study conducted at Deghabour district of Ethiopian Somalia region (Mohamed and Gebeyew, 2018) which was $139.10 \mathrm{~cm}$. But, a study conducted by Yesihak (2008) revealed that height of Rhodes plants grown sole on savannah regions of Ethiopia at 8 weeks after sowing varied from 100.7 to $121.0 \mathrm{~cm}$ tall. On the other hand FAO (2009) discovered that Rhodes grass (Chloris gayana) grows up to the height of 90 centimeters.

\subsection{Dry Matter Yield}

The aboveground dry matter biomass yield indicates that, there is a significant difference $(P<0.05)$ observed among the mean mass values Rhodes grass (Chloris gayana) cultivars. The mean aboveground dry matter biomass yields (t/ha) obtained were 7.79, 7.53, 7.95, 9.42 and 8.5 for ILRI-7384, CV-massaba-13329, ILRI-6633, DZ-253 and local check respectively (Table 1). Comparatively, DZ-253 and local check give higher (i.e. 9.42 and 8.5 respectively) aboveground dry matter yield ( $\mathrm{t} / \mathrm{ha}$ ) than the rest treatments. Nevertheless, CV-massaba13329 gives the least aboveground dry matter yield per hectare than other Rhodes grass (Chloris gayana) cultivars. Growth performance of Rhodes grass varies with type of cultivar, age of plant and other environmental factors (FAO, 2009). Rhodes grass productivity generally ranges from 7 - 25 tons of DM/ha per year, depending on variety, soil fertility, environmental conditions and cutting frequency (Cook et al, 2005, CASCAPE, 2015 and HARC, 2004).

The average aboveground dry matter biomass yield values of Rhodes grass cultivars recorded in this study were almost similar with other studies conducted by different authors. Based on a study conducted on farmers' fields in the central highlands of Ethiopia, on average the herbage yield of Rhodes grass was from 8.74 to 9.1 tons $\mathrm{DMha}^{-1}$ per year on rain-fed conditions (Cook et al., 2005, CASCAPE, 2015 and HARC, 2004). Additionally, a study conducted at Adami Tulu Agricultural Research Center (ATARC) and Negele Arsi Farmers Training Center (FTC) also indicated that the average herbage dry biomass yield of Rhodes grass was from 7.8 to 9.16 tons $\mathrm{DM} / \mathrm{ha}^{-1}$ per year without manure application (Tesfaye et al., 2020) which is almost similar with this study. 


\subsection{Seed Yield}

The seed yield outcome indicates that, there is a significant difference $(P<0.05)$ observed among the mean seed yield values Rhodes grass (Chloris gayana) cultivars. The over year mean seed yield values $(\mathrm{kg} / \mathrm{ha})$ attained was 265.3, 252.0, 275.7, 291.3 and 280.6 for ILRI-7384, CV-massaba-13329, ILRI-6633, DZ-253 and local check respectively (Table 1). Relatively, DZ-253 and local check gave higher seed yield than the rest cultivars which was 291.3 and $280.6 \mathrm{Kg} / \mathrm{ha}$ respectively. Seed yield obtained was lower than other studies (Tesfaye et al., 2020 and Dawit et al., 2020) which were conducted at Adami Tulu Agricultural Research Center (ATARC) and Negele Arsi Farmers Training Center (FTC). The mean seed yield values recorded were 370.55 and 313.88 $\mathrm{Kg}$ /ha by Tesfaye et al., (2020) and Dawit et al., (2020) respectively. This variation in seed yield productivity might be due the difference in soil fertility and soil moisture factors. On the other hand, climate and soil types or their interactions have effects on the performance of forage crops as indicated by Diriba et al., (2014).

\section{Conclusion and Recommendation}

Five treatments of Rhodes grass (Chloris gayana) namely ILRI-7384, CV-massaba-13329, ILRI-6633, DZ-253 and local check were evaluated for agronomic parameters such as days to emergence, days to $50 \%$ flowering, plant height $50 \%$ flowering and dry biomass yield per hectare. The overall statistical analysis result indicates that there is a significant difference $(P<0.05)$ observed among mean value of treatments for days to emergence (DE), days to $50 \%$ flowering (DF\%) and dry matter yield per hectare. The least number of days to emergence and days to $50 \%$ flowering was recorded by local check and ILRI-7384 respectively. The highest dry biomass yield per hectare was recorded by cultivar DZ-253 even if it requires more number of days to emergence and days for $50 \%$ flowering comparative to the rest four treatments. From forage science point of view, cultivars that are producing higher above ground dry biomass yield are priority and recommended for advanced production in the study area. On the other hand days to full maturity (DFM) and plant height (PH) parameters statistical analysis result showed that there is no significance difference $(P>0.05)$ observed among the mean values of all treatments; but, all treatments have a numerical difference.

Based on study result it recommended Rhodes grass (Chloris gayana) cultivars DZ-253 and local check for the study area and other districts having similar soil and agro-ecology because it gives higher dry biomass yield. Further studies will be needed on how to increase the productivity of Rhodes grass (Chloris gayana) cultivars using different natural fertilizer rates and how to intercrop with other legume forage species for the sake of obtaining its optimum productivity of this forage technology in the study area. On the other hand a study must be conducted on selecting the best Rhodes grass (Chloris gayana) forage establishment strategy as it is well understood that there is scarcity of land in the study area.

\section{Acknowledgements}

The author acknowledges the Oromia Agricultural Research Institute (OARI) for funding and other technical supports. The authors accept responsibility for all remaining errors and omissions.

\section{References}

Akinola JO, Olorunju SAS (1990). Changes in herbage yield and quality of indeginoust and introduced forage species with age. Journal Animal Production Research 10(1): 1-20.

CASCAPE (2015). Capacity building for Scaling up of evidence-based practices in Agricultural Production in Ethiopia.

Cook BG, Pengelly BC, Brown SD, Donnelly JL, Eagles DA, et al. (2005). Tropical Forages: an interactive selection tool, [CD-ROM], CSIRO, DPI\&F (Qld), CIAT and ILRI, Brisbane, Australia.

Diriba G, Mekonnen H, Ashenafi M, Adugna T., 2014. Biomass yield potential and nutritive value of selected Alfalfa (Medicagosativa.) cultivars grown under tepid to cool sub-moist agro-ecology of Ethiopia. E3 Journal of Agricultural Research and Development Vol. 4(1). Pp. 007-014, January, 2014.

Duke JA (1997). Rhodes grass (Chloris gayana Kunth) In: Handbook of Energy Crops (Unpublished). Centre for New Crops and Plant Products, Purdue University.

Ecocrop (2014). Ecocrop database. FAO, Rome, Italy.

FAO (2009). Rhodes grass (Chloris gayana Kunth). Food and Agricultural Organization of the United Nations (FAO)

FAO (2014). Grass land Index. A searchable catalogue of grass and forage legumes. FAO, Rome, Italy.

Frans Swane poel, A. S., and Siboniso Moyo, 2010. The Role of Livestock in Developing Communities:Enhancing Multifunctionality 978-0, 86886- 7984.

HARC (Holetta Agricultural Research Center) (2004). Feed Resources Development and Utilization: Possible Options and Recommendations under Ethiopia Condition.

Ibrahim, H. \& Olaloku, E. (2000). Improving Cattle for Milk, Meat and Traction, ILRI (aka ILCA and ILRAD).

Melkamu Bezabih Yitbarek, G. B. (2014). Livestock Production Systems Analysis: Review. 1. 
Mohamed A, Gebeyew K (2018) On-farm Performance Evaluation of Selected Perennial Grass under Rain-Fed Conditions at Deghabour District, Cherer Zone, Ethiopian Somali Region. Poult Fish Wildl Sci 6: 201. doi: 10.4172/2375-446X.1000202

Moore G (2006). Rhodes grass Dept Agric Food Western Australia Bull 4690 Perth.

Tesfaye, A. Girma, C. Daniel, W. Dawit, A. (2020). Effect of Different Levels of Cattle Manure on Biomass, Seed Yield and Crude Protein Content of Rhodes Grass. Journal of Natural Sciences Research. Vol.10, No.9. ISSN 2224-3186.

Yesihak K (2008). Effect of seed proportion of Rhodes grass (Chloris gayana Kunth) and White seed clover (Melilotus alba) at sowing on agronomic characteristics and nutritional quality. Livestock Research for Rural Development.

Yvan, O. and Tessema, Z. (2007). An assessment of grazing lands potentialities in Ordola surroundings (Erer districts) of Shinile zone. Handicap International, Dire Dawa, Ethiopia. pp.75
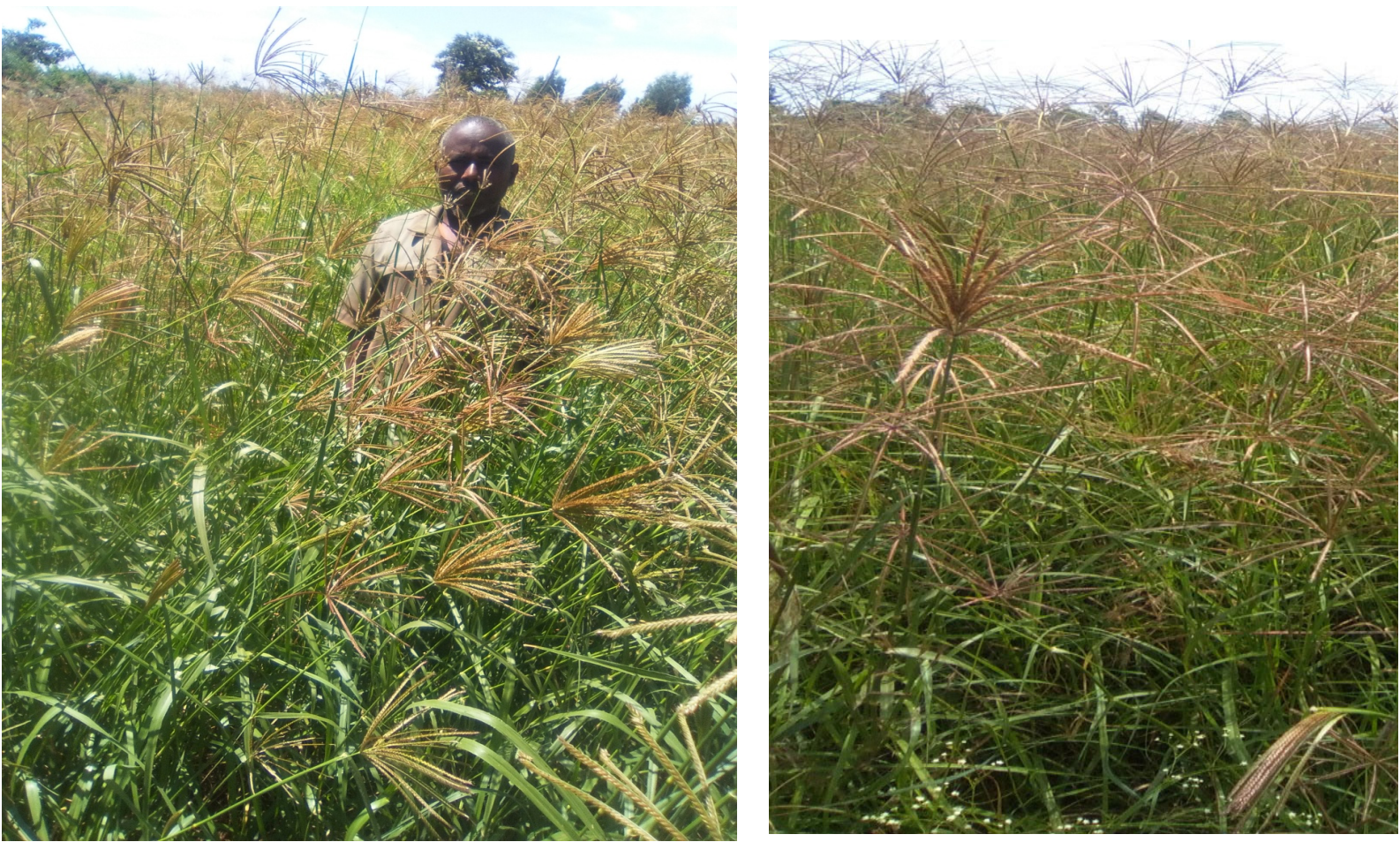

Figure 1. Figures taken during the implementation of the activity. 